\title{
ANALISIS KEMAMPUAN TPACK (TECHNOLGICAL, PEDAGOGICAL, AND CONTENT, KNOWLEDGE) GURU BIOLOGI SMA DALAM MENYUSUN PERANGKAT PEMBELAJARAN MATERI SISTEM PEREDARAN DARAH
}

\author{
Joko Suyamto ${ }^{1}$, Mohammad Masykuri², Sarwanto $^{3}$ \\ 1,2,3 Universitas Sebelas Maret, Surakarta, 57126. \\ Email Korespodensi: djokersuper38@gmail.com
}

Diajukan: 1 January 2020; Diterima: 2 February 2020; Diterbitkan: 30 April 2020

\begin{abstract}
Abstrak: Perkembangan ilmu pengetahuan dan teknologi bisa dijadikan salah satu cara untuk meningkatkan kualitas pembelajaran yang dilakukan oleh seorang guru. Untuk bisa mewujudkan hal tersebut, seorang guru perlu memahami dan mimiliki kemampuan Technological Pedagogical Content Knowledge (TPACK) yang merupakan pengembangan dari Pedagogical Content Knowledge (PCK)-nya Shulman (1986). TPACK merupakan pengetahuan untuk mengintegrasikan teknologi ke dalam pengajaran materi tertentu. Penelitian ini bertujuan untuk mengetahui kemampuan guru biologi di SMA dalam aspek TPACK. Jenis penelitian ini adalah penelitian deskriptif kuantitatif dengan teknik cluster sampling. Sampel yang digunakan adalah 3 guru biologi di 3 sekolah (selanjutnya diberi kode B1, B2, dan B3) se - kecamatan gondang. Data dikumpulkan melalui metode observasi. Hasil penelitian menunjukkan bahwa pemahaman materi / Content knowledge (CK) guru B1 sebesar 76\%, B2 sebesar $80 \%$ dan B3 sebesar 72\% dalam kategori baik. Skor pada pengetahuan pedagogical knowledge (PK) guru B1 sebesar 50\%, B2 sebesar 45\%, dan B3 sebesar 60\%. Skor pada pengetahuan technological knowledge (TK) guru B1 sebesar 48,5\%, B2 sebesar 40\%, dan B3 sebesar 40\%. Skor pada aspek Technological content knowledge (TCK) guru B1 sebesar 60\%, guru B2 60\% dan guru B3 40\%. Skor pada aspek technological pedagogical knowledge (TPK) guru B1 60\%, B2 67\%, dan B3 60\%. Skor aspek pedagogical conten knowledge (PCK) guru B1 60\%, guru B2 40\%, dan B3 54\%. Skor pengetahuan TPACK guru B1 47\%, guru B2 47\%, dan B3 $60 \%$.
\end{abstract}

Kata Kunci : Perangkat Pembelajaran, TPACK, Guru SMA, Sistem Peredaran Darah

\begin{abstract}
The development of science and technology can be used as a way to improve the quality of learning carried out by a teacher. To be able to make this happen, a teacher needs to understand and have the ability of Technological Pedagogical Content Knowledge (TPACK) which is the development of Shulman's Pedagogical Content Knowledge (PCK) (1986). TPACK is the knowledge to integrate technology into the teaching of certain materials. This study aims to determine the ability of biology teachers in high school in the TPACK aspect. This type of research is descriptive quantitative research with cluster sampling technique. The samples used were 3 biology teachers in 3 schools (hereinafter coded B1, B2, and B3) throughout Gondang sub-district. Data were collected through the observation method. The results showed that the understanding of the material / Content knowledge (CK) of B1 teachers was 76\%, B2 was $80 \%$ and B3 was $72 \%$ in the good category. The score on the pedagogical knowledge (PK) of B1 teachers is 50\%, B2 is 45\%, and B3 is 60\%. The score on the technological knowledge (TK) of B1 teachers is 48.5\%, B2 is 40\%, and B3 is 40\%. Scores on the Technological content knowledge (TCK) aspect of B1 teachers are 60\%, B2 teachers are 60\% and B3 teachers are 40\%. The scores on the technological pedagogical knowledge (TPK) aspects of teachers are B1 60\%, B2 67\%, and B3 60\%. Scores of pedagogical content knowledge (PCK) aspects of B1 teachers are 60\%, B2 teachers are 40\%, and B3 are $54 \%$. TPACK knowledge scores of B1 teachers 47\%, B2 teachers 47\%, and B3 60\%.
\end{abstract}

Keywords: Learning Devices, TPACK, High School Teachers, Circulatory System

\section{Pendahuluan}

Tantangan perkembangan dunia semakin berorientasi menuntut tersedianya sumber daya manusia (SDM) yang menguasai ilmu pengetahuan, teknologi dan seni (IPTEKS). Perubahan dunia yang semakin cepat harus diiringi dengan praktik pendidikan yang relevan dengan tuntutan perubahan tersebut. Fenomena seperti itu terjadi secara menonjol berkenaan dengan perkembangan teknologi informasi dan komunikasi (ICT). Perkembangan teknologi informasi telah mengubah berbagai aspek kehidupan manusia, tak terkecuali dalam bidang pendidikan (Wasitohadi, 2009). Diawal tahun 2006 
perkembangan teknologi pendidikan berkembang ke arah pemecahan masalah belajar paradigma ini diorientasikan untuk menjabarkan teknologi pendidikan agar dapat mengatasi masalah belajar secara lebih terarah dan terkendali ( Raiser, 2008). Menyimak perkembangannya, teknologi pendidikan dapat dikatakan sebagai suatu proses sistematik dalam membantu memecahkan masalah masalah dalam pembelajaran (Miarso, 2004).

Sebagian besar guru baru menyadari akan pentingnya teknologi untuk pendidikan/ pembelajaran, namun belum berupaya untuk menerapkannya (Wasitohadi, 2009). Guru merupakan salah satu faktor penentu keberhasilan dalam proses pembelajaran. Kualitas guru merupakan faktor penting dalam meningkatkan kualitas pendidikan, seperti catatan dalam laporan McKinsey yang menyatakan bahwa " kualitas sistem pendidikan tidak mungkin melampui kualitas gurunya " (Barber dan Mourshed, 2007, 16). Guru bertugas merencanakan dan melaksanakan proses pembelajaran, menilai, melakukan penelitian dan pengkajian serta membuka komunikasi dengan masyarakat (Sagala, 2009). Undang - undang nomor 14 tahun 2005 pasal 8 tentang guru dan dosen menerangkan bahwa guru wajib memiliki kualifikasi akademik S1/D4, kompetensi, sertifikat pendidik, sehat jasmani dan rohani, serta memiliki kemampuan untuk mewujudkan tujuan pendidikan nasional (Chang, dkk, 2014). Sedangkan pada pasal 10 menyatakan bahwa kompetensi guru sebagaimana dimaksud dalam pasal 8 meliputi kompetensi pedagogik, kompetensi kepribadian, kompetensi sosial, dan kompetensi profesional yang diperoleh melalui pendidikan profesi. Namun data guru dari sensus PMPTK kemendiknas (SIMPTK, 2006) menyatakan bahwa hanya 37 persen dari semua guru memiliki kualifikasi tersebut. Guru yang bermutu adalah guru yang menguasai keempat kompetensi guru dan profesionalitas dalam memfasilitasi siswanya untuk belajar (Ridla, 2008).

Guru sebagai pendidik wajib memiliki kemampuan pedagogik, antara lain pengembangan kurikulum, silabus dan perencanaan pembelajaran. Dalam undang undang nomor 20 Tahun 2003 tentang sistem pendidikan nasional berfungsi mengembangkan kemampuan dan karakter serta peradaban bangsa yang bermartabat dalam rangka mencerdaskan kehidupan bangsa. Untuk itu guru harus mampu mengembangkan perangkat pembelajaran berbasis kemampuan dan karakter untuk menjadi alat mencapai tujuan pendidikan nasional. Dapat disimpulkan bahwa guru memiliki peranan dalam mendidik sebagai sumber belajar, fasilitator, pengelola, demonstrator, pembimbing dan motivator (Sanjaya, 2013).

Fakta dilapangan dijumpai bahwa sekolah dan guru di Indonesia masih memiliki permasalahan antara lain adalah standar guru, penguasaan materi, dan rendahnya media dan teknologi / Literacy media and Technology. Tidak ada perbedaan kualitas pendidikan Indonesia sebelum dan sesudah sertifikasi guru dilaksanakan. Bahkan Bank Dunia menegaskan bahwa sertifikasi guru tidak memperlihatkan dampak yang nyata terhadap hasil pendidikan walaupunsudah menghabiskan dana yang cukup besar (Joope De Ree, dkk, 2012). Menurut Sopan Adrianto, Wakil Kepala Dinas Pendidikan DKI Jakarta menyatakan bahwa tunjangan yang diberikan pemerintah terkait sertifikasi ternyata tidak berdampak maskimal pada kinerja guru, dan kemampuan pedagogik guru juga lebih rendah, dan ia menyatakan bahwa dengan adanya sertifikasi ini guru bukan memikirkan bagaimana meningkatkan profesionalitas dan kompetensi tetapi hanya memikirkan bagaimana memperbanyak sertifikasi (http : // cnnindonesia.com/ dipublikasi pada 11/06/2015/ 16.07). Ditambah dengan hasil Uji Kompetensi Guru tahun 2012 yang di rilis oleh Kemendikbud RI memperlihatkan bahwa rata - rata guru di Indonesia baru mencapai nilai 44 dari skala 100 (http://ukg.kemendikbud.go.id).

Tantangan berat yang dihadapi dunia pendidikan di Indonesia dalam kompleks global adalah kemampuan guru dalam merancang perencanaan pengembangan kompetensi guru yang disebut dengan TPACK atau Technological Pedagogical Content Knowledge. TPACK merupakan integrasi pengetahuan dan ketrampilan yang komprehensif dalam hal materi, dan pedagogi yang dipadukan dalam perkembangan teknologi. TPACK pertama kali dicetuskan oleh Shulman (1987) dan dikembangkan oleh Koehler \& Mishra (2008). TPACK dianggap sebagai kerangka kerja berpotensi yang dapat 
memberikan arah baru bagi guru dalam memecahkan masalah terkait dengan mengintegrasikan TIK ke dalam kegiatan belajar mengajar di ruang kelas (Hewitt, 2008).

TPACK (Technological Pedagogical Content Knowledge) yang dicetuskan oleh Shulman (1987) tentang PCK (Pedagogical Content Knowledge) yang menjelaskan tentang teknologi pendidikan dan interaksi PCK satu dengan yang lain untuk menciptakan pembelajaran yang efektif dengan penggunaan teknologi. Kemudian konsep TPACK dikembangkan oleh Punya Mishra dan Matetew JJ. Koehler (2008) oleh karena adanya perkembangan teknologi yang pesat di masyarakat. Mishra \& Koehler (2008) menjelaskan bahwa prinsip TPACK merupakan penggabungan teknologi, pedagogi, isi / materi yang diterapkan dalam satu konteks. Kerangka TPACK hasil dari pengembangan Mishra \& Koehler sebagaimana gambar 1 .

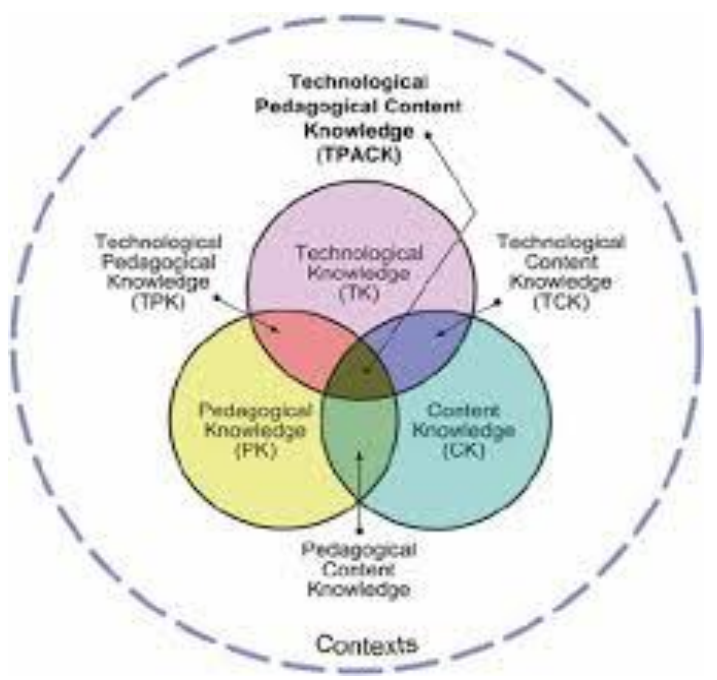

Gambar 1. Framework TPACK dari Mishra \&Koehler (2008)

Komponen TPACK dijelaskan dalam www.tpack.org oleh Mishra \& Koehler (2008) bahwa "TPACK is an emergent from of knowledge that goes beyond all three core component (Content, Pedagogy, and Technology), technological pedagogical content knowledge is an understanding that emerges from interactions among content, pedagogy and technology knowledge". TPACK adalah dasar dari mengajar efektif dengan teknologi, memerlukan pemahaman tentang representasi dari konsep - konsep yang menggunakan teknologi, teknik pedagogis yang menggunakan teknologi dalam cara yang kontruktif untuk mengajarkan materi, pengetahuan tentang apa yang membuat konsep sulit atau mudah untuk belajar dan bagaimana teknologi dapat membantu memperbaiki beberapa masalah yang dihadapi siswa dan teori epistemologi, dan pengetahuan tentang bagaimana teknologi dapat digunakan untuk membangun pengetahuan untuk mengembangkan metode / cara baru atau memperkuat yang lama.

TPACK adalah kerangka kerja yang mencoba memahami hubungan antara pengetahuan tentang pengajaran (pedagogical knowledge), dan penggunaan teknologi (technologi knowledge). Dalam TPACK, pengetahuan guru untuk mengintegrasikan teknologi dalam pembelajaranmembuat pembelajaran menjadi efektif dan efisien. Integrasi teknologi dianggap sebagai sebagai komponen pengajaran yang terkait erat dan termasuk juga dalam PCK (Oyanagi dan Satake, 2016).

Guru profesional harus memiliki kompotensi TPACK yang memadai, karena TPACK berada dalam ranah empat kompetensi utama seorang guru yang meliputi kompetensi pedagogik, kompetensi kepribadian, kompetensi sosial dan kompetensi profesional. Doering, Veletsianos, Schrber, \& Miller (2009) dalam penelitiannya menayatakan bahwa pengintegrasian TPACK mampu meningkatkan kepercayaan diri serta peningkatan kompetensi konten, pedagogis, dan teknologi guru dalam mendesain pembelajaran. Oleh sebab itu pola pengembangan kompetensi guru dengan TPACK merupakan jalan yang sesuai untuk menjamin terlaksananya pembelajaran yang sesuai dengan tuntutan dan perubahan yang terjadi. Sebelum dilakukan pengembangan kompetensi guru, harus dianalisis kondisi kemampuan TPACK guru yang akan menjadi landasan perumusan kebijakan. TPACK dianggap sebagai framework yang dapat memberikan arah baru bagi guru untuk memecahkan masalah tentang bagaimana mengintegrasikan TIK ke dalam pembelajaran di kelas (Hewitt, 2008).

\section{Metode Penelitian}

Jenis penelitian ini adalah deskriptif dengan pendekatan kuantitatif, dengan pengambilan sampel dengan teknik cluster 
sampling. Dari 6 sekolah di Kecamatan Gondang, sebanyak 3 sekolah dipilih berdasarkan kriteria jenis sekolah yaitu sekolah swasta. Jumlah responden pada setiap SMA yang terlibat ditentukan dengan teknik random sampling yaitu 1 guru dari setiap sekolah yang mengajar di kelas XI dari 3 sekolah SMA / MA yang berada di Kecamatan Gondang kabupaten Sragen. Data yang diperoleh di lapangan melalui observasi diolah dengan menggunakan analisis kuantitatif. Selanjutnya data tersebut dianalisis dengan metode Miles dan Huberman yaitu reduksi data (Sugiyono, 2013).

Teknik dan alat yang digunakan untuk mengumpulkan data penelitian adalah dengan lembar observasi pembelajaran. Data penelitian yang diperoleh akan dianalisis dengan statistik deskriptif dan analisis dokumen.

Prosedur analisis data dihasilkan dari instrumen penelitian yang menggunakan skala Likert sesuai dengan tabel 1 :

\begin{tabular}{ll}
\multicolumn{1}{c}{ Tabel 1. Kategori Skala Likert } \\
\hline \multicolumn{1}{c}{ Interval } & \multicolumn{1}{c}{ Kriteria } \\
\hline $3,25<$ skor $\leq 4,00$ & Sangat Baik (SB) \\
$2,50<$ skor $\leq 3,25$ & Baik (B) \\
$1,75<$ skor $\leq 2,50$ & Kurang $(\mathrm{K})$ \\
$1,00<$ skor $\leq 1,75$ & Sangat Kurang) \\
\hline
\end{tabular}

(Widyoko, 2014)

Rumus yang digunakan untuk mengubah skor yang diperoleh ke dalam bentuk persentase, sebagai berikut.

$$
\text { Nilai }=\frac{\text { skor yang diperoleh }}{\text { skor maksimum }} \times 100 \%
$$

Data yang diperoleh selanjutnya diubah dalam kreteria kualitatatif pada tabel 2.

Tabel 2. Rentang Persentase dan Kreteria Kualitatif

\begin{tabular}{cll}
\hline Nilai & Rentang & Kriteria Kualitatif \\
\hline 1 & $0-20$ & Sangat kurang \\
2 & $21-40$ & Kurang \\
3 & $41-60$ & Cukup \\
4 & $61-80$ & Baik \\
5 & $81-100$ & Sangat baik \\
\hline
\end{tabular}

(Sugiyono, 2013)

\section{Hasil Penelitian dan Pembahasan}

Data yang diperoleh dari observasi terhadap guru di SMA Gondang diberi kode B1, guru di MA Nahdlatul Ulama Gondang diberi kode B2, dan guru di MA Nurul Huda Gondang diberi kode B3. Analisis TPACK terbagi menjadi beberapa aspek yaitu, Technological Knowledge (TK), Pedagogical
Knowledge (PK), Content Knowledge (CK), Technological Pedagogical Knowledge (TPK), Pedagogical Content Knowledge (PCK) dan Technological Content Knowledge (TCK).

\section{Content Knowledge (CK)}

Content Knowledge merupakan pengetahuan tentang terhadap mata pelajaran yang akan dipelajari atau diajarkan (Schmidt, dkk., 2009). Content knowledge mengarah kepada pengetahuan atau kekhususan disiplin ilmu atau pelajaran. Content knowledge ini berbeda di tiap tingkatannya mulai dari tingkat dasar hingga tingkat sekolah menengah dasar. Seorang guru diharapkan menguasai kemampuan ini untuk mengajar. Content knowledge juga penting karena kemampuan tersebut menentukan cara kekhasan berfikir dari disiplin ilmu pada setiap kajiannya.

Data hasil analisis kemampuan content knowledge pada tiga sekolah didapatkan hasil rata - rata sebesar $76 \%$ pada kategori baik. Pada tebel 2 dapat dilihat bahwa B1 memiliki skor $76 \%$ pada kategori baik, B2 memiliki skor 80 $\%$ pada kategori baik, dan B3 memiliki skor $72 \%$ pada kategori baik. Hasil ini menunjukkan bahwa responden telah memiliki kemampuan dalam menguasai materi yang baik dan diajarkan kepada siswa dengan baik.

Tabel 3. Analisis kemampuan aspek CK

\begin{tabular}{llll}
\hline No & $\begin{array}{l}\text { Kode } \\
\text { Guru }\end{array}$ & $\begin{array}{l}\text { Skor } \\
(\boldsymbol{\%})\end{array}$ & $\begin{array}{l}\text { CK } \\
\text { Kreteria } \\
\text { kualitatif }\end{array}$ \\
\hline 1 & B1 & 76 & Baik \\
2 & B2 & 80 & Baik \\
3 & B3 & 72 & Baik \\
\hline & Rata -rata & 76 & Baik \\
\hline
\end{tabular}

Selanjutnya semua skor masing - masing komponen pada bagian CK untuk semua guru dapat dilihat secara jelas pada tabel 4. Data ini menunjukkan bahwa kemampuan masing masing komponen dikategorikan cukup dengan nilai rata - rata 3,8 pada kategori cukup.

\begin{tabular}{|c|c|c|c|}
\hline No & & Komponen CK & Rerata \\
\hline 1 & & Menguasai materi yang diajarkan & 4 \\
\hline 2 & & $\begin{array}{l}\text { Memberikan contoh - contoh yang } \\
\text { relevan dalam meningkatkan } \\
\text { pemahaman siswa }\end{array}$ & 4 \\
\hline \multirow[t]{3}{*}{3} & & $\begin{array}{l}\text { Menyampaikan materi secara logis, } \\
\text { jelas dan sesuai dengan RPP }\end{array}$ & 3,4 \\
\hline & 44 & $\begin{array}{l}\text { Menjawab pertanyaan siswa dengan } \\
\text { tepat }\end{array}$ & 3,4 \\
\hline & 55 & $\begin{array}{lrr}\text { Menggunakan sumber } & \text { terbaru } \\
\text { seperti buku, jurnal, } & \text { untuk } \\
\text { meningkatkan khazanah } & \text { ilmu } \\
\text { biologi yang dimiliki. } & \end{array}$ & 4 \\
\hline
\end{tabular}




\section{Pedagogical Knowledge (PK)}

Pedagogical knowledge merupakan proses mengajar yang melibatkan metode termasuk pengetahuan mengelola kelas, memberikan penilaian, mengembangkan rencana pembelajaran dan proses belajar siswa (Schmidt, dkk., 2009). Pedagogical knowledge mendeskripsikan tujuan umum pengetahuan dalam mengajar. Kemampuan mengajar merupakan ketrampilan yang harus dikembangkan oleh guru supaya mampu mengelola dan mengorganisir kelas dalam aktifitas pembelajaran dan dapat mencapai tujuan yang telah ditentukan.

Pengetahuan yang diharapkan meliputi pemahaman aktifitas pengelolaan kelas, peran motivasi siswa, rencana pembelajaran, dan penilaian pengajaran. Kemampuan pedagogical knowledge juga mendeskripsikan pengetahuan dari metode mengajar yang berbeda - beda meliputi pengetahuan untuk mengetahui bagaimana mengorganisasikan aktivitas kelas yang kondusif.

Analisis kemampuan aspek pedagogical knowledge pada tiga sekolah mempunyai rata rata yaitu 51,6 \% pada kategori cukup. Pada tabel 5 dapat diketahui B1 mempunyai skor $50 \%$ pada kategori cukup, B2 mempunyai skor $45 \%$ pada kategori cukup, dan B3 mempunyai skor 60 pada kategori cukup. Hasil ini menunjukkan bahwa kemampuan dalam menguasai pedagogi pembelajaran adalah cukup.

\begin{tabular}{llll}
\multicolumn{5}{c}{ Tabel 5. Analisis kemampuan aspek PK } \\
\hline No & $\begin{array}{l}\text { Kode } \\
\text { Guru }\end{array}$ & $\begin{array}{l}\text { Skor PK } \\
(\%)\end{array}$ & $\begin{array}{l}\text { Kriteria } \\
\text { kualitatif }\end{array}$ \\
\hline 1 & B1 & 50 & Cukup \\
2 & B2 & 45 & Cukup \\
3 & B3 & 60 & Cukup \\
& Rata - rata & 51,6 & Cukup \\
\hline & Rata & rata & kemampuan untuk tiap
\end{tabular}

indikator PK terhadap 3 guru dapat dilihat pada tabel 6.

\begin{tabular}{lll}
\multicolumn{3}{c}{ Tabel 6. Nilai rata - rata komponen PK } \\
\hline No & Komponen PK & Rerata \\
\hline 6 & $\begin{array}{l}\text { Memiliki strategi / cara yang bervariasi } \\
\text { dalam menanamkan konsep kepada siswa }\end{array}$ & 2,6 \\
7 & $\begin{array}{l}\text { Menggunakan metode dan teknik penilaian } \\
\text { yang bervariasi }\end{array}$ & 2,3 \\
8 & $\begin{array}{l}\text { Menguasai dan mengelola kelas dengan } \\
\text { baik }\end{array}$ & 2,6 \\
\hline
\end{tabular}

\begin{tabular}{lll}
\hline 9 & $\begin{array}{l}\text { Melakukan tindakan reflektif untuk 2,6 } \\
\text { meningkatkan kualitas pembelajaran }\end{array}$ \\
\hline
\end{tabular}

\section{Tecknological Knowledge (TK)}

Technological knowledge merupakan pengetahuan tentang beragam teknologi dari mulai yang terendah hingga teknologi paling terbaru yaitu teknologi digital. Penggunaan teknologi harus disesuaikan dengan perkembangan zaman dan berkembang secara kontinu. Technological knowledge meliputi pemahaman bagaimana menggunakan sofeware dan hardware komputer atau teknologi dalam konteks pendidikan. Tecknological knowledge meliputi kemampuan adaptasi dan mempelajari teknologi terbaru. Kemampuan tersebut perlu dimiliki karena perkembangan dan perubahan teknologi yang terus berkembang.

Analisis kemampuan technological knowledge pada 3 guru dalam mengelola perangkat pembelajaran mempunyai skor sata sata yaitu $42,8 \%$ pada kategori cukup. Pada tabel 7 menunjukkan nilai pada responden B1 adalah 48,5\% pada kategori cukup, B2 sebesar 40\% pada kategori kurang, dan B3 sebesar 40 pada kategori kurang. Kemampuan terhadap penguasaan pengetahuan teknologi dari ketiga responden mempunyai rata - rata cukup, namun pada responden B2 dan B3 mempunyai pengetahuan kurang, sehingga harus meningkatkan pengetahuan terhadap penggunaan teknologi.

Tabel 7. Nilai rata - rata aspek TK

\begin{tabular}{llll}
\hline No & Kode Guru & Skor TK $(\%)$ & Kreteria kualitatif \\
\hline 1 & B1 & 48,5 & Cukup \\
2 & B2 & 40 & Kurang \\
3 & B3 & 40 & Kurang \\
\hline & Rata - rata & 42,8 & Cukup \\
\hline
\end{tabular}

Selanjutnya semua skor masing masing komponen pada aspek TK untuk 3 guru dapat dilihat pada tabel 8 .

\begin{tabular}{lll}
\multicolumn{4}{c}{ Tabel 8. Nilai pada komponen TK } \\
\hline No & \multicolumn{1}{c}{ Komponen TK } & Rerata \\
\hline 10 & $\begin{array}{l}\text { Menguasai teknologi yang digunakan } \\
\text { dengan baik }\end{array}$ & 2,3 \\
11 & $\begin{array}{l}\text { Teknologi yang digunakan memiliki daya } \\
\text { tarik bagi siswa }\end{array}$ & 2,3 \\
12 & $\begin{array}{l}\text { Teknologi yang digunakan berhasil } \\
\text { meningkatkan minat dan motivasi siswa } \\
\text { Teknologi yang digunakan mudah untuk } \\
\text { dioperasikan } \\
\text { Teknologi yang digunakan sesuai dengan } \\
\text { perkembangan zaman } \\
\text { Teknologi yang digunakan sesuai dengan } \\
\text { tingkat pemahaman siswa }\end{array}$ & 2,3 \\
\hline
\end{tabular}




\begin{tabular}{lcl}
\hline No & Komponen TK & Rerata \\
\hline 16 & $\begin{array}{l}\text { Teknologi yang digunakan } \\
\text { memecahkan masalah }\end{array}$ & membantu \\
\hline
\end{tabular}

\section{Technological Content Knowledge (TCK)}

Schmidt, dkk. (2000), mengemukakan bahwa TCK sebagai penegtahuan tentang bagaimana teknologi dapat menciptakan sebuah gambaran baru terhadap materi tertentu. Guru dapat melakukan pendekatan baru menggunakan TCK terhadap sebuah materi untuk selankutnya diajarkan kepada siswa. TCK mendeskripsikan pengetahuan dari hubungan timbal balik antara teknologi dan konten (materi). Teknologi akan berdampak pada apa yang diketahui dan pengenalan terhadap hal baru sehingga akan mempengaruhi bagaimana seseorang dapat memberikan gambaran pada konten (materi) dengan cara berbeda dari sebelumnya.

Analisis kemampuan 3 guru dalam technological content knowledge mempunyai skor rata - rata 53,3 \% pada kategori cukup. Pada tabel 9 menunjukkan kemampuan yang bervariasi, responden B1 mempunyai skor $60 \%$ pada kategori cukup, responden B2 mempunyai skor $60 \%$ pada kategori cukup, dan responden B3 mempunyai skor $40 \%$ pada kategori kurang. Responden mempunyai kemampunan dalam menggunakan teknologi yang bevariasi.

Tabel 9. Nilai rata - rata aspek TCK

\begin{tabular}{llll}
\hline No & Kode Guru & $\begin{array}{l}\text { Skor TCK } \\
(\boldsymbol{\%})\end{array}$ & $\begin{array}{l}\text { Kreteria } \\
\text { kualitatif }\end{array}$ \\
\hline 1 & B1 & 60 & Cukup \\
2 & B2 & 60 & Cukup \\
3 & B3 & 40 & Kurang \\
\hline & Rata - rata & 53,3 & Cukup \\
\hline
\end{tabular}

Analisis data terhadap rata - rata kemampuan aspek TCK untuk ketiga guru dapat dilihat pada tabel 10 .

Tabel 10. Nilai pada komponen TCK

\begin{tabular}{llc}
\hline No & \multicolumn{1}{c}{ Komponen TCK } & Rerata \\
\hline 17 & $\begin{array}{l}\text { Teknologi yang digunakan relevan dengan } \\
\text { materi yang diajarkan }\end{array}$ & 3 \\
18 & $\begin{array}{l}\text { Teknologi yang digunakan dapat } \\
\text { meningkatkan pemahaman siswa }\end{array}$ & 2,6 \\
19 & $\begin{array}{l}\text { Mengembangkan aktivitas dan tugas siswa } \\
\text { yang melibatkan penggunaan teknologi }\end{array}$ & 2,3 \\
\hline
\end{tabular}

\section{Technological Pedagogical Knowledge (TPK)}

Technological Pedagogical Knowledge (TPK) merupakan pengetahuan tentang bagaimana beragam teknologi dapat digunakan dalam pengajaran dan penggunaan teknologi tersebut mampu mengubah cara guru mengajar (Schmidt, dkk. 2009). TPK terjadi karena adanya hubungan timbal balik antaa teknologi dan pedagogi. Pengetahuan tersebut memungkinkan untuk memahami penggunaan teknologi apa yang tepat untuk mecapai tujuan pedagogi, serta memungkinkan guru untuk memilih media yang tepat berdasarkan kelayakan dan pendekatan pedagogi tertentu.

Teknologi dapat memberikan metode baru yang digunakan dalam proses mengajar dan dapat memudahkan untuk diaplikasikan dalam pembelajaran. Sebagai contoh pembelajaran sistem online learning yang disebabkan oleh perkembangan dan kebutuhan masyarakat menuntut guru dan pengajar lebih inovatif dan kreatif.

Analisis kemampuan guru di tiga sekolah pada aspek TPK mempunayi skor rat - rata $62,3 \%$. Responden B1 mempunyai skor $60 \%$ pada kategori cukup, B2 mempunyai skor $67 \%$ pada kategori baik, dan B3 mempunyai skor $60 \%$ pada kategori cukup.

Tabel 11. Nilai rata - rata aspek TPK

\begin{tabular}{|c|c|c|c|}
\hline No & Kode Guru & $\begin{array}{l}\text { Skor TPK } \\
(\%)\end{array}$ & $\begin{array}{l}\text { Kreteria } \\
\text { kualitatif }\end{array}$ \\
\hline 1 & B1 & 60 & Cukup \\
\hline 2 & B2 & 67 & Baik \\
\hline \multirow[t]{3}{*}{3} & B3 & 60 & Cukup \\
\hline & Rata - rata & 62,3 & Cukup \\
\hline & Rata - & rata & ipuan \\
\hline
\end{tabular}

komponen TPK ketiga guru dapat dilihat pada tabel 12.

Tabel 12. Nilai pada komponen TPK

\begin{tabular}{llc}
\hline No & Komponen TPK & Rerata \\
\hline 20 & $\begin{array}{l}\text { Menggunakan aplikasi komputer dalam } \\
\text { pembelajaran }\end{array}$ & 3,3 \\
21 & $\begin{array}{l}\text { Memilih teknologi yang sesuai dengan } \\
\text { pendekatan dan strategi pembelajaran } \\
22\end{array}$ & 3 \\
& $\begin{array}{l}\text { Menggunakan fasilitas internet untuk } \\
\text { berkomunikasi dengan siswa misalnya } \\
\text { untuk mengumpulkan tugas atau bahan } \\
\text { ajar. }\end{array}$ & 3 \\
\hline
\end{tabular}

Pedagogical Content Knowledge (PCK)

Pedagogical content knowledge yaitu pengetahuan pedagogi yang berlaku untuk 
pengajran konten yang spesifik. Pengetahuan ini termasuk untuk mengetahyui pendekatan apa yang tepat untuk proses pengajaran dan mengetahui bagaimana elemen konten dapat diatur untuk pembelajaran yang baik (Mishra \& Koehler, 2006). Shulman (1986) menyatakan bahwa pengajaran efektif memerlukan lebih dari sekedar pemisahan materi dan pedagogi. PCK juga mengakui kenyataan bahwa konten yang berbeda akan cocok dengan metode mengajar yang berbeda. PCK memiliki makna lebih dari sekedar ahli konten atau tahu pedoman umum pedagogis, tetapi lebih kepada pemahaman kekhasan saling mempengaruhi konten dan pegagoginya.

Analisis kemampuan 3 guru dalam aspek PCK mempunyai nilai rata - rata $51,3 \%$ pada kategori cukup. Tabel 13 menunjukkan bahwa responden B1 mempunyai skor $60 \%$ pada kategori cukup, B2 mempunyai skor $40 \%$ pada kategori kurang, dan B3 mempunyai skor 54 pada kategori cukup. Dari data tersebut dapat dilihat bahwa responden mempunyai kemampuan menyajikan materi yang beragam.

\begin{tabular}{|c|c|c|c|}
\hline No & $\begin{array}{l}\text { Kode } \\
\text { Guru }\end{array}$ & $\begin{array}{l}\text { Skor } \\
\text { PCK }(\%)\end{array}$ & $\begin{array}{l}\text { Kreteria } \\
\text { kualitatif }\end{array}$ \\
\hline 1 & B1 & 60 & Cukup \\
\hline 2 & B2 & 40 & Kurang \\
\hline \multirow[t]{2}{*}{3} & B3 & 54 & Cukup \\
\hline & Rerata & 51,3 & Cukup \\
\hline
\end{tabular}

komponen PCK ketiga guru mata pelajaran dapat dilihat pada tabel 14 .

Tabel 14. Nilai pada komponen TCK

\begin{tabular}{llr}
\multicolumn{4}{c}{ Tabel 14. Nilai pada komponen TCK } \\
\hline No & \multicolumn{1}{c}{ Komponen TCK } & Rerata \\
\hline 23 & $\begin{array}{l}\text { Memilih pendekatan dan strategi } \\
\text { pembelajaran yang sesuai dengan } \\
\text { materi kimia yang di ajarkan }\end{array}$ & 2,3 \\
24 & $\begin{array}{l}\text { Memberikan soal - soal untuk } \\
\text { mengukur pemahaman siswa } \\
\text { mengenai materi yang diakarkan }\end{array}$ & 3 \\
25 & $\begin{array}{l}\text { Mempersiapkan RPP sendiri dan } \\
\text { dikonsultasikan dengan Pengawas }\end{array}$ & 2,3 \\
\hline
\end{tabular}

\section{Technological Pedagogical and Content Knowledge (TPACK)}

TPACK merupakan pengetahuan tentang interaksi yang kompleks domain prinsip pengetahuan (konten, pedagogi, teknologi). Pembelajaran pada masa modern menuntut pemahaman guru untuk bisa mengkolaborasikan dengan teknologi. Jadi tidak hanya aspek pedagogi saja tetapi aspek konten dan teknologi juga menjadi pertimbangan dalam hal pelaksanaan pembelajaran di kelas yang modern dan inovatif. Guru harus memiliki pemahaman terhadap interaksi kompleks antara 3 komponen dasar yaitu PK, CK, dan TK dengan cara mengajarkan materi menggunakan metode pedagogik dan teknologi yang sesuai (Mishra \& Koehler, 2006).

Kerangka TPACK juga berfungsi sebagai sebuah teori dan konsep untuk peneliti dan pendidik dalam mengukur kesiapan calon guru atau guru dalam mengajar efektif dengan penggunaan teknologi. TPACK akan berdampak pada guru mengingat hubungan teknologi, pedagogi, dan konten tidak dapat dipisahkan. Sehingga guru akan menghadapi lebih besar tantangan di masa mendatang dan berbanding lurus dengan perkembangan teknologi. Sudah seharusnya guru menjadi aktif dalam pengembangan dan desain pembelajaran maupun kurikulum.

Penelitian mengenai Technological Pedagogical Content Knowledge (TPACK) telah dilakukan oleh Chai, Koh, \& Tsai (2013). Penelitian tersebut menelaah sekitar 74 literatur meliputi jurnal dan artikel yang terkait dengan TPACK. Hasil penelitian tersebut secara tidak langsung menyatakan bahwa guru memerlukan TPACK untuk pembelajaran efektif di kelas meskipun penelitian lebih mendalam mengenai TPACK masih perlu dilakukan. Kerangka TPACK memiliki dampak yang signifikan terhadap guru dan pendidik guru. Kerangka TPACK mendeskripsikan berbagai jenis pengetahuan yang guru butuhkan untuk mengajar secara efektif dengan bantuan teknologi dan berbagai prsedur yang kompleks dalam bidang interaksi pengetahuannya.

Analisis kemampuan 3 guru dalam aspek TPACK mempunyai rata - rata $51,3 \%$ pada kategori cukup. Tabel 15 menunjukkan persentase skor dari 3 responden. Responden B1 mempunyai skor 47 pada kategori cukup, B2 mempunyai skor 47 pada kategori cukup, dan B3 mempunyai skor 60 pada kategori cukup. Dari data tersebut dapat dilihat bahwa 3 responden mempunyai penguasaan integrasi materi, penyajian dan penggunaan teknologi yang cukup, namun harus ada upaya maksimal dalam aplikasi dalam pembelajaran sehingga dapat meningkatkan hasil belajara dan motivasi siswa. 
Tabel 15. Nilai rata - rata aspek TPACK

\begin{tabular}{|c|c|c|c|}
\hline No & $\begin{array}{l}\text { Kode } \\
\text { Guru }\end{array}$ & $\begin{array}{l}\text { Skor TPACK } \\
(\%)\end{array}$ & $\begin{array}{l}\text { Kreteria } \\
\text { kualitatif }\end{array}$ \\
\hline 1 & B1 & 47 & Cukup \\
\hline 2 & B2 & 47 & Cukup \\
\hline \multirow[t]{2}{*}{3} & B3 & 60 & Cukup \\
\hline & Rerata & 51,3 & Cukup \\
\hline
\end{tabular}

Hasil perolehan skor rata- rata dalam aspek TPACK dapat dilihat pada tabel 16.

Tabel 16. Nilai rata - rata setiap komponen TPACK

\begin{tabular}{lll}
\hline No & Komponen TPACK & Rerata \\
\hline 26 & $\begin{array}{l}\text { Memilih strategi pembelajaran dan } \\
\text { teknologi yang sesuai dengan materi }\end{array}$ & 2,6 \\
& kimia yang akan digunakan pada \\
& $\begin{array}{l}\text { kegiatan pembelajaran } \\
27\end{array}$ & $\begin{array}{l}\text { Memadukan pengetahuan biologi, 2,3 } \\
\text { pengetahuan pedagogi, dan } \\
\text { pengetahuan teknologi yang dimiliki }\end{array}$ \\
& dalam mewujudkan pembelajaran \\
& efektif \\
Menerapkan strategi pembelajaran 2,6 \\
yang tepat dan menggunakan \\
aplikasi komputer yang beragam \\
dalam pelaksanaan pembelajaran
\end{tabular}

Dari data tabel 16 bahwa ketiga guru sudah cukup mampu dalam menggunakan teknologi dan mengintegrasikannya ke dalam proses pembelajaran yang efektif sehingga dapat merubah cara guru mengajar dan meningkatkan pemahaman siswa. Setelah dilakukan analisis keseluruhan data tersebut didapat hasil rata - rata setiap aspek TPACK yang disajikan pada gambar 2 .

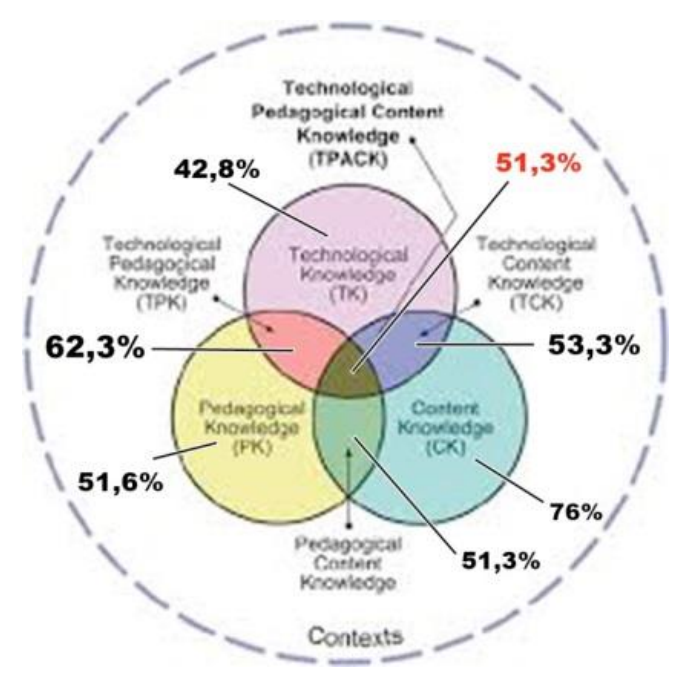

Gambar 2. Diagram persentase rata - rata kemampuan TPACK guru SMA

Gambar 2 diatas dapat dilihat bahwa TPACK terdiri dari beberapa aspek yang digabung menjadi satu yaitu, technological knowledge (TK), pedagogicali knowledge
(PK), Content knowledge (CK), Technological content knowledge (TCK), pedagogical conten knowledge (PCK), technological pedagogical knowledge (TPK).

Berdasarkan kriteria kualitatif pada tabel 1 bahwa kemampuan guru di SMA tergolong cukup baik untuk semua komponen TPACK. Presentase tertinggi pada aspek CK dengan skor $72 \%$, sementara persentase terendah terdapat pada TK yaitu $42,8 \%$. Faktor yang menyebabkan perolehan persentase kegiatan pada aspek TK kurang baik karena masih banyak guru yang belum bisa mengintegrasikan antara TK, Ck, dan PK dengan baik. Hal ini sesuai dengan penelitian yang dilakukan oleh Hayati (2014), bahwa semua aspek dalam TPACK mempengaruhi secara signifikan terhadap keberhasilan integrasi antara TPACK dengan pembelajaran. TPACK sangat penting bagi kemampuan menyusun perangkat pembelajaran, guru dapat menggunakan teknologi dengan baik dalam kegiatan pembelajaran, jika guru dapat mengintegrasikan enam jenis pengetahuan ke dalam perangkat pembelajaran yang disusunnya (Harris, dkk., 2011). Hasil penelitian ini sesuai dengan hasil penelitian yang dilakukan oleh Graham, dkk. (2012) yang meneliti kemampuan TPACK pada guru.

Penelitian mengenai TPACK telah dilakukan oleh Chai, Koh \&Tsai (2013). Penelitian tersebut menelaah 74 literatur meliputi jurnal dan artikel terkait dengan TPACK. Hasil penelitian secara tidak langsung menyatakan bahwa guru memerlukan TPACK untuk pembelajaran efektif dikelas meskipun penelitian lebih mendalam mengenai TPACK masih perlu di lakukan. Kerangka TPACK memiliki dampak yang signifikan terhadap guru dan pendidik. Kerangka TPACK mendeskripsikan berbagai jenis pengetahuan yang guru butuhkan untuk mengajar secara efektif dengan bantuan teknologi dan berbagai prosedur yang kompleks mengenai bidang interaksi pengetahuaanya. Menurut NCTM (2000), penggunaan teknologi dalam pembelajaran berpengaruh pada apa yang diajarkan dan kapan suatu materi pembelajaran muncul di dalam kurikulum. Oleh karena itu, guru perlu guru perlu memastikan bahwa penggunaan teknologi dalam pembelajaran tersebut efektif. 
Berdasarkan penelitian Lestari (2015, 557), beberapa fakta yang mempengaruhi kemampuan TPACK guru adalah banyaknya pengalaman belajar yang didapat oleh pemerintah dengan tujuan untuk meningkatkan kualitas guru. Sehingga lamanya pengalaman mengajar tidak berbanding lurus dengan peningkatan kemampuan TPACK. Hal ini dipengaruhi oleh banyak faktor, antara lain kesibukan yang dihadapi oleh guru senir, sehingga menyebabkan para guru senior tidak dapat menyempatkan waktunya untuk mempelajari hal yang baru, terutama kemajuankemajuan teknologi dalam mendukung proses pengajaran di kelas. Oleh karena itu, sebagian besar guru senior masih banyak yang menerapkan metode pembelajarankonvensional. Sebaliknya para guru yang memiliki pengalaman mengajar 11 15 tahun dapat melakukan transformasi di dalam kelasnya menggunakan teknologi. Hal ini dikarenakan kesibukan guru yang memiliki pengalaman mengajar 11-15 tahun, tidak sebanyak kesibukan yang dimiliki oleh guru yang memiliki pengalaman mengajar 16 tahun atau lebih.

\section{Simpulan, Saran, dan Rekomendasi}

Berdasarkan hasil analisis kemampuan TPACK guru dalam mengembangkan perangkat pembelajaran dengan sampel 3 guru SMA di kec- Gondang Kabupaten Sragen, dapat disimpulkan bahwa kemampuanTPACK guru tergolong cukup baik dengan skor technological knowledge (TK) sebesar 42,8\%, pedagogical knowledge (PK) sebesar 51,6\%, Content knowledge (CK) sebesar 76\%, Technological content knowledge (TCK) sebesar 53,3\%, pedagogical conten knowledge (PCK) sebesar 51,3\%, technological pedagogical knowledge (TPK) sebesar 62,3\% dan TPACK sebesar 51,3\%. Pemanfaatan teknologi informasi dan komunikasi dalam pembelajaran bisa jadi alternatif untuk perbaikan tersebut. Untuk mampu mengitegrasikan teknologi informasi dan komunikasi dalam mengajar diperlukan kerangka Technological Pedagogical Content Knowledge (TPACK) oleh seorang guru. Oleh karena itu sudah seharusnya guru di Indonesia memiliki kemampuan tersebut agar bisa mewujudkan tujuan pendidikan nasional sehingga bangsa Indonesia bisa bersaing dengan bangsa lainnya di era Masyarakat Ekonomi Asean (MEA) saat ini.

\section{Daftar Pustaka}

Barber, M., \& Mourshed, M. (2007). How the World's Best Performing Schools Come Out on Top. New York: McKinsey \& Company.

Chai, C. -S., Koh, J. H. -L., \& Tsai, C. -C. (2013). A Review of Technological Pedagogical Content Knowledge. EducationalTechnology \& Society, 16 (2), $31-51$.

Chang, M., S. Shaeffer, S. Al-Samarrai, A. Ragatz, J. de Ree and R. Stevenson. (2014). Teacher Reform in Indonesia: The Role of Politics and Evidence in Policy Making. Directions in Development, No. 16355. Washington, DC: World Bank.

Direktorat Jenderal Peningkatan Mutu Pendidik dan Tenaga Kerja (PMPTK). (2008). Data Basis Guru. SIMPTK 2006 PMPTK (Direktorat Jenderal Peningkatan Mutu Pendidik dan Tenaga Kependidikan). 2008 Presentation on costs associated with the Teacher Law of 2005, Yogyakarta, Indonesia.

Harris, J. B., \& Hofer, M. J (2011). Technological Pedagogical Content Knowledge (TPACK) in Action : A Descriptive Study of Secondary Teachers' Curriculum Base, Technology Related Instructional Planning. Journal of Research on Technologi in Education, 43 : 211- 229.

Hayati, D. K., Sutrisno, \& Lukman, A. (2014). Pengembangan Kerangka Kerja TPACK pada Materi Koloid untuk Meningkatkan Aktivitas Pembelajaran dalam Mencapai HOTS Siswa. Edusains, 3: 53- 61.

Hewitt, J. (2008). Reviewing the handbook of technological pedagogical pedagogical content knowledge (TPACK) for educators. Canadian Journal of Science, Mathematics, and Technology Education, 8 (4), $355-360$.

Hofer, Mark dan Judi Harris. (2012). "TPACK Research with Inservice Teachers: Where's the TCK?. Proceedings of Society for Information Technology \& Teacher Education International Conference", (Online), (http://www.editlib.org/p/40 52., diakses pada 10 Januari 2019

http://ukg.kemdikbud.go.id. Diakses pada 25 januari 2019/17.40

Joope De Ree, dkk. (2012). Penelitian untuk Bank Dunia, "Transforming Indonesia's Teaching Force."http://www.worldbank.org/in/countr y/indonesia/brief/world-bank-and educationin-indonesia

Koehler, M. J., \& Mishra, P. (2008). What Is Technological Pedagogical Content 
Knowledge? Contemporary Issues in Technology and Teacher Education. CITE Journal, 9(1), 60-70

Lestari, Suci. (2015). Analisis Kemampuan Technological Pedagogical Content Knowledge (TPACK) pada Guru Biologi SMA dalam Materi Sistem Saraf. Seminar Nasional XXI Pendidikan Biologi FKIP UNS. 557- 563.

Miarso, Y. (2004). Menyemai Benih Teknologi Pendidikan. Jakarta : Prenada Media dan Pustekom Diknas.

Mishra, P. dan M. J. Koehler. (2006). Technological Pedagogical Content Knowledge: A Framework for Teacher Knowledge. Teachers College Record. 6 (108): 10171058.

Mulyasa, E. (2005). Menjadi Guru Profesional Menciptaklan Pembelajaran Kreatif dan Menyenangkan. Bandung : Remaja Rosdakarya.

NCTM. (2000). Principles and Standards for School Mathematics. Reston, VA: The National Council of Teacher of Mathematics, Inc. Retrieved from. http://webapp1.dlib.indiana.edu/virtual_disk library/index.cgi/4273355/FID3542/DOCS /ENC2280/28023310.HTM

Oyanagi, W. And Satake, Y. (2016). Capacity Building in Technological pedagogical Content Knowledge for Preservise Teacher. International Journal for Educational Media and Technology, 10 (1), $33-44$
Reiser, R and Gagne, R. M. 2008. The selection of Media for Instruction. Englewood Cliffs, $\mathrm{Nj}$. Educational Technology Publications.

Ridla, M. (2008). Profesionalitas Guru Pendidikan Agama Islam dalam Proses Pembelajaran. Tadris, 3(1), 30-44.

Sagala, Syaiful. (2009). Konsep dan Makna Pembelajaran. Bandung : Alfabeta.

Sanjaya, Wina. (2013). Penelitian Pendidikan, Jenis, Metode, dan Prosedur. Jakarta : Kencana Prenada Media Grup.

Schmidt A., Denise dkk. (2009). Technological Pedagogical Content Knowledge (TPACK): The Development and Validation of an Assessment Instrument for Preservice Teachers. Journal of Research and Technology Education, XLII (2): 123-149.

Shulman, L. S. (1986). Those Who Understand, Knowledge Growth in Teaching. Educational Researcher Vol. 15, No, 2, Page 4-14.

Sugiyono. (2013). Metode Penelitian Pendidikan Pendekatan Kuantitatif, Kualitatif, dan $R \& D$. Bandung: ALFABETA. 2012 (cet. 15)

Sukirman, (2012). Pengembangan Media Pembelajaran. Yogyakarta : Pedagogia.

Warsito, Hadi (2009). Hubungan Antara Self Efficacy dengan Penyesuaian Akademik dan Prestasi Akademik (Studi Kasus pada Mahasiswa FIP Universitas Negeri Surabaya) Jurnal Ilmiah Pendidikan, Vol. IX. No, 1 